\title{
Pengaruh Penggunaan Biji Asam Jawa (Tamarindus indica) sebagai Pengganti Bekatul Terhadap Kualitas Karkas dan Berat Organ Dalam Ayam Pedaging
}

\author{
The Effect of Using Tamarind Seeds (Tamarindus indica) as replacemtnfor Rice Bran \\ on Carcass Quality and Internal Organ Weight in Broilers
}

\author{
Osfar Sjofjan*, Danung Nur Adli, David Christian Sembiring \\ Fakultas Peternakan Universitas Brawijaya, Malang, Jl. Veteran, Jawa Timur 65145 \\ *Korespondensi E-mail: osofjan@yahoo.com
}

Diterima 15 Mei 2020; Disetujui 15 Februari 2021

\begin{abstract}
ABSTRAK
Biji asam jawa mempunyai potensi besar sebagai penggati bekatul. Penelitian ini dilakukan dengan tujuan untuk mengetahui pengaruh penggantian bekatul dengan tepung biji asam jawa dalam pakan terhadap bobot karkas, persentase karkas, dan organ dalam ayam pedaging. Metode yang digunakan dalam penelitian adalah Rancangan Acak Lengkap yang terdiri dari 5 perlakuan : P0 = Jagung $60 \%+$ konsentrat 30\% + bekatul 10\% ( kontrol ), P1 = Jagung 60\% + konsentrat 30\% + bekatul 7,5\% + tepung biji asam jawa 2,5\%, P2 = Jagung 60\% + konsentrat 30\% + bekatul 5\% + tepung biji asam jawa 5\%, P3 = Jagung 60\% + konsentrat 30\% + bekatul 2,5\% + tepung biji asam jawa 7,5\%, P4 = Jagung $60 \%+$ konsentrat $30 \%+$ bekatul $0 \%$ + tepung biji asam jawa 100\%, dengan 4 kali pengulangan dan pada setiap ulangan terdiri dari 5 ekor ayam pedaging. Penggantian bekatul dengan tepung biji asam jawa dilakukan pada saat umur ternak 21 hari pemeliharaan. Variabel penelitian yang diamati terdiri dari bobot karkas, persentase karkas dan berat organ dalam ayam pedaging. Pengunaan tepung biji asam jawa sebagai pengganti bekatul memberikan pengaruh tidak berbada nyata $(\mathrm{P}>0,05)$ terhadap berat karkas ayam pedaging. Pemberian tepung biji asam jawa sebagai pengganti bekatul dalam pakan belum mampu meningkatkan bobot karkas, persentase karkas dan berat organ dalam ayam pedaging.
\end{abstract}

Kata kunci: Biji Asam, Broiler, Karkas, dan Organ Dalam

\begin{abstract}
The tamarind had potential to replacement rice bran as poultry feed. The research purposes were to replace the rice bran with tamarind flour on carcass weight, carcass percentage, and organ weight of broiler. The method used were completely randomised design with five treatments four replicates. The treatments as follows: $\mathrm{T} 0=$ maize $60 \%+$ concentrate $30 \%+$ rice bran $10 \%$ (control) $\mathrm{T} 1=$ maize $60 \%+$ concentrate $30 \%+$ rice bran $7,5 \%+$ tamarind flour $2,5 \%, \mathrm{~T} 2=$ maize $60 \%+$ concentrate $30 \%+$ rice bran $5 \%+$ tamarind flour $5 \%$, T3 $=$ maize $60 \%+$ concentrate $30 \%+$ rice bran $2,5 \%+$ tamarind flour $7,2 \%$, $\mathrm{T} 4=$ maize $60 \%+$ concentrate $30 \%+$ tamarind flour $10 \%$. The parameter observed were carcasse percentage and relatively organ weight. The result showed the replacement of tamarind flour were not significant difference $(p>0.05)$ to carcass and relative orgn weight of broiler. In summary, the replacement rice bran with tamarind flor didnt help increase to carcass and relative organ weight of broiler.
\end{abstract}


Keywords: Broiler, Tamarind Seed Flour, Carcass Weight, Carcass Percentage, and Internal Organs

\section{PENDAHULUAN}

Pertambahan jumlah penduduk di Indonesia dari tahun ke tahun terus mengalami peningkatan, hal ini akan berdampak pada peningkatan konsumsi produk peternakan (daging) yang secara tidak langsung memberikan peluang usaha dalam memajukan industri peternakan Indonesia termasuk perunggasan. Ternak unggas memberikan kontribusi yang besar terhadap pemenuhan gizi khususnya protein hewani. Berdasarkan data dari Dirjen Peternakan dan Kesehatan Hewan (2018), ayam ras pedaging merupakan komponen terbesar dalam produksi daging ternak lainnya sebesar $67 \%$. Ayam ras pedaging atau broiler merupakan salah satu jenis ternak ayam yang mudah dipelihara, pertumbuhannya cepat, dan murah biaya pemeliharaannya. Output akhir dari broiler adalah daging yang merupakan sumber protein asal hewani yang banyak dikonsumsi oleh masyarakat, dan harganya relatif terjangkau.

Pemeliharaan ayam pedaging dapat berhasil merupakan salah satunya ditentukan oleh pakan. Pakan menghabiskan kurang lebih 60-70\% dari biaya produksi (Pasaribu, 2007). Dalam pengembangan usaha ayam pedaging, umumnya peternak menggunakan pakan komersil yang telah disesuaikan dengan kebutuhan nutrisinya. Pengaruh iklim sangat menentukan ketersediaan pakan untuk ayam pedaging. Untuk mengatasi hal tersebut biasanya petani peternak memberi pakan sisa-sisa pertanian. Pakan alternatif yang berasal dari limbah pertanian/industri dapat dipertimbangkan untuk dimanfaatkan dalam usaha peternakan. Limbah pertanian yang tersedia sepanjang tahun dan umumnya berkualitas rendah dari segi kandungan protein dan juga kandungan serat yang tinggi, seperti bekatul, ampas tahu dan onggok (Adli et al., 2017).

Bekatul merupakan bahan pakan limbah pertanian yang banyak dipakai untuk pakan ternak, mudah didapat dan harganya relatif murah karena bekatul merupakan produk sampingan dari penggilingan padi. Kandungan protein yang rendah, serat kasar yang tinggi dan adanya asam jawa fitat yang mampu mengikat mineral Ca serta protein menjadi garam fitat dan fitat protein menyebabkan kecernaan pada unggas menjadi rendah (Adli et al., 2019). Kandungan zat gizi yang dimiliki bekatul yaitu protein 13,11-17,19\%, lemak 2,525,05\%, karbohidrat 67,58 - 72,74\%, dan serat kasar $37 \%-38,3 \%$ (Widiyawati dkk., 2020). Salah satu cara untuk meningkatkan kecernaan adalah dengan memanfaatkan limbah 
pertanian lain sebagai pengganti bekatul. Salah satu bahan alternatif adalah pemanfaatan biji asam jawa (Tamarindus indica) (Widiyawati dkk, 2020).

Biji asam jawa mempunyai potensi yang sangat besar, karena merupakan tanaman asli Indonesia, mudah dibudidayakan, dan merupakan salah satu limbah pertanian yang selama ini telah banyak digunakan oleh masyarakat Nusa Tenggara Timur sebagai salah satu bahan pakan ternak. Produktivitas biji asam jawa lebih tinggi dibandingkan dengan kacang kedelai, yakni berkisar 1,5-4 ton dalam satu hektar sedangkan untuk kedelai rata-rata produksinya hanya 1,3 ton dalam satu hektar (Adli and Sjofjan, 2018). Disisi lain, biji asam jawa mempunyai potensi besar karena dapat dipanen lebih dari 5 kali dalam sekali tanam dengan hasil biji kering lebih dari 1 ton/ha sekali panen (Adli et al., 2018), dapat tumbuh dan berproduksi pada lahan yang kurang subur, biaya budidaya lebih murah dibandingkan dengan kedelai, harga murah, kandungan protein cukup tinggi 30\%, mengandung lisin dan triptofan yang relatif tinggi, kandungan karbohidrat 67,23\%, kandungan lemak kasar 1,9\%. Kandungan nutrisi biji asam jawa mengandung protein kasar 13,12\%, lemak kasar 3,98\%, serat kasar 3,67\%, bahan kering 89,14\%, kalsium 1,2\%, phospor 0,11\%, abu 3,25\%, BETN $75,98 \%$, dan energi metabolis $3368 \mathrm{Kkal} / \mathrm{kg}$, namun mempunyai kendala defisiensi metionin dan sistin serta mengandung anti nutrisi yaitu tripsin inhibitor, asam jawa fitat dan tanin (Widiyawati dkk., 2020).

Berdasarkan hal itu maka dilakukan penelitian terhadap beberapa perlakuan penggantian protein dari bekatul dengan biji asam jawa dalam pakan ternak ayam pedaging yang tujuan untuk mengetahui pengaruhnya terhadap nilai kualitas produksi ayam pedaging meliputi bobot karkas, persentase karkas, dan berat organ dalam ayam pedaging.

\section{MATERI DAN METODE}

\section{Materi}

Materi penelitian yang digunakan pada penelitian ini adalah Ayam pedaging yang digunakan dalam penelitian ini adalah ayam pedaging umur satu hari (DOC) strain Lohman produksi PT. Japfa Comfeed Indonesia Tbk, jumlah ayam yang digunakan dalam penelitian sebanyak 100 ekor dan tidak dibedakan jenis kelaminnya (unisexed) dengan rata-rata bobot badan $40,00 \pm 4,7 \mathrm{~g}$.

Pada saat pemeliharaan, pakan yang digunakan dibagi menjadi dua tahapan jenis pakan yang di berikan. Pada saat umur 1-20 hari pakan yang dipakai merupakan pakan 
lengkap atau feed complet, sedangkan pada umur 21-35 hari menggunakan pakan perlakuan dimana bekatul pada pakan diganti dengan menggunakan tepung biji asam jawa. Pakan yang digunakan berupa crumble dan diberikan untuk ayam pedaging mulai dari DOC hingga berumur 35 hari. Pakan diberikan di nampan dan diberikan secara ad libitum. Pakan yang digunakan pada penelitian ini terdiri dari jagung kuning, konsentrat jadi produksi PT. Japfa Comfeed Indonesia Tbk, bekatul dan tepung biji asam jawa yang nanti dicampur berdasarkan presentase penggunaan bahan pakan. Sebelum dilakukan pencampuran bahan pakan sebelumnya dilakukan uji proksimat untuk mengetahui kandungan energi metabolis dan protein.

Tabel 1. Kandungan Zat Makanan Bahan Pakan Penelitian.

\begin{tabular}{lcccccc}
\hline Bahan pakan & EM (Kkal/g) & PK (\%) & SK (\%) & LK (\%) & Ca (\%) & P (\%) \\
\hline Jagunga $^{\mathrm{a}}$ & 3.226 & 9,2 & 2,74 & 5,46 & 0,01 & 0,26 \\
Konsentrat $^{\mathrm{b}}$ & 2.700 & 41 & 5 & 5 & 2,50 & 1,40 \\
Bekatul $^{\mathrm{a}}$ & 2.860 & 12 & 12 & 3 & 0,04 & 1,40 \\
$\begin{array}{l}\text { Tepung Biji } \\
\text { Asam Jawa }\end{array}$ & 3.368 & 13,12 & 3,67 & 1,9 & 1,2 & 0,11 \\
\hline
\end{tabular}

Keterangan: a: Widiyawati dkk., (2020), b: Label pakan konsentrat PT. Japfa Comfeed, c: Hasil Analisis Laboratorium Pakan Ternak Dinas Peternakan dan Perikanan Blitar (Sjofjan et al., 2020).

Tabel 2. Komposisi dan Kandungan Pakan Percobaan Ayam Pedaging Fase Finisher

\begin{tabular}{lccccc}
\hline \multirow{2}{*}{ Bahan pakan } & \multicolumn{5}{c}{ Komposisi (\%) } \\
\cline { 2 - 6 } & P0 & P1 & P2 & P3 & P4 \\
\hline Jagung & 50 & 50 & 50 & 50 & 50 \\
Konsentrat & 40 & 40 & 40 & 40 & 40 \\
Bekatul & 10 & 7,5 & 5 &, 5 & - \\
Tepung Biji Asam Jawa & - & 2,5 & 5 & 7,5 & 10 \\
\hline Total & 100 & 100 & 00 & 00 & 00 \\
\hline Energi(Kkal/g) & 2979 & 2992,01 & 3004,71 & 3017,41 & 3030,11 \\
PK (\%) & 22,22 & 22,22 & 22,25 & 22,28 & 22,31 \\
SK (\%) & 4,57 & 4,36 & 4,15 & 3,94 & 3,73 \\
LK (\%) & 5,03 & 5,00 & 4,97 & 4,94 & 4,92 \\
Ca (\%) & 1,01 & 1,03 & 1,06 & 1,09 & 1,12 \\
P (\%) & 0,83 & 0,79 & 0,76 & 0,73 & 0,70 \\
\hline
\end{tabular}

Keterangan: Hasil perhitungan berdasarkan kandungan bahan pakan yang tersaji pada Tabel 2

Metode Penelitian yang digunakan adalah percobaan lapang dengan Rancangan Acak 
Lengkap. Perlakuan dimulai pada umur 21-35 hari dengan menggunakan sebanyak 5 perlakuan dan masing-masing dilakukan pengulangan sebanyak 4 kali dengan jumlah ayam per unit 5 ekor dan total 20 unit percobaan. Penelitian ini dilakukan dengan memberikan tepung biji asam jawa dengan rincian perlakuan sebagai berikut

$$
\begin{aligned}
& \text { P0 = Jagung } 60 \%+\text { konsentrat } 30 \%+\text { bekatul 10\% (kontrol) } \\
& \text { P1 = Jagung } 60 \%+\text { konsentrat } 30 \%+\text { bekatul 7,5\% + tepung biji asam jawa 2,5\% } \\
& \text { P2 = Jagung } 60 \%+\text { konsentrat } 30 \%+\text { bekatul } 5 \%+\text { tepung biji asam jawa } 5 \% \\
& \text { P3 = Jagung } 60 \%+\text { konsentrat 30\% + bekatul 2,5\% + tepung biji asam jawa 7,5\% } \\
& \text { P4 = Jagung } 60 \%+\text { konsentrat 30\% + bekatul } 0 \%+\text { tepung biji asam jawa } 100 \%
\end{aligned}
$$

\section{Analisis Data}

Data yang diperoleh dianalisis menggunakan analisis ragam dari Rancangan Acak Lengkap (RAL) menggunakan aplikasi SAS version 9.4. Apabila hasil penelitian menunjukkan pengaruh nyatta $(\mathrm{P}<0,05)$ atau sangat nyata $(\mathrm{P}<0,01)$ maka dilanjutkan dnegan Uji Jarak Berganda Duncan's (UJBD). Metode dalam RAL yang digunakan adalah sebagai berikut:

$$
\begin{aligned}
& Y i j=\mu+n i+\varepsilon i j \\
& \text { Keterangan : } \\
& \text { Yij = Nilai pengamatan pada perlakuan ke-i ulangan ke } \mathrm{j} \\
& \mu \quad=\text { Nilai tengah umum } \\
& \text { пі } \quad=\text { Pengaruh perlakuan ke-i } \\
& \text { Eij } \quad=\text { Kesalahan (galat) percobaan pada perlakuan } \\
& \text { i } \quad=\text { Perlakuan ke } 0,1,2,3,4 \\
& \text { j = Ulangan ke- } 1,2,3,4
\end{aligned}
$$

\section{HASIL DAN PEMBAHASAN}

Hasil analisis statistik menunjukkan bahwa pengunaan tepung biji asam jawa sebagai pengganti bekatul memberikan pengaruh tidak berbada nyata $(P>0,05)$ terhadap berat karkas ayam pedaging. Data perhitungan statistik berat karkas dapat dilihat pada Tabel 3. 
Hasil rata-rata berat karkas (g/ekor) yang tertinggi hingga terendah adalah P4 (1612,75 $\pm 6,18)$, P3 $(1550,75 \pm 13,05)$, P2 $(1450 \pm 140,92)$, P1 $(1368,75 \pm 17,65)$, P0 $(1343,25 \pm 13,15)$. Berdasarkan data yang didapatkan pada Tabel 3, penggunaan tepung biji asam jawa sebagai pengganti bekatul belum dapat meningkatkan hasil karkas ayam pedaging dikarenakan di dalam tepung biji asam mengandung protein yang tinggi yaitu sebesar 30\% serta kandungan karbohidrat sebesar $67,23 \%$ sehingga dapat di manfaatkan sebagai bahan pakan ayam (Leke et.al., 2013).

Tabel 3. Pengaruh Perlakuan Terhadap Berat Karkas, Presentase Karkas, dan Berat Organ Dalam Ayam Pedaging.

\begin{tabular}{lccccc}
\hline \multirow{2}{*}{ Variabel } & \multicolumn{5}{c}{ Perlakuan } \\
\cline { 2 - 6 } & PO & P1 & P2 & P3 & P4 \\
\hline $\begin{array}{l}\text { Berat Karkas } \\
\text { (g/ekor) }\end{array}$ & $1343,25 \pm 13,15$ & $1368,75 \pm 17,65$ & $1450,25 \pm 9,88$ & $1550,75 \pm 13,05$ & $1612,75 \pm 6,18$ \\
Karkas (\%) & $69,57 \pm 4,56$ & $70,51 \pm 0,45$ & $71,30 \pm 0,87$ & $72,33 \pm 1,79$ & $74,76 \pm 0,48$ \\
Hati (\%) & $1,71 \pm 0,17$ & $1,94 \pm 0,19$ & $2,15 \pm 0,14$ & $2,00 \pm 0,13$ & $1,81 \pm 0,17$ \\
Jantung (\%) & $0,43 \pm 0,04$ & $0,42 \pm 0,02$ & $0,39 \pm 0,04$ & $0,36 \pm 0,03$ & $0,43 \pm 0,11$ \\
Gizzard (\%) & $2,91 \pm 0,21$ & $2,95 \pm 0,17$ & $2,65 \pm 2,4$ & $2,68 \pm 0,21$ & $2,93 \pm 0,24$ \\
Limpa (\%) & $0,30 \pm 0,11$ & $0,15 \pm 0,10$ & $0,15 \pm 0,04$ & $0,40 \pm 0,34$ & $0,18 \pm 0,17$ \\
\hline
\end{tabular}

\section{Pengaruh Perlakuan Terhadap Berat Karkas Ayam Pedaging}

Biji asam jawa (Tamarindus indica) di giling menjadi tepung sehingga memudahkan ternak (ayam pedaging) mengkonsumsi dan mencerna pakan yang sudah dicampur dengan tepung biji asam . Fungsi dari karbohidrat sendiri adalah sebagai sumber energi, karbohidrat yang tersusun berasal dari unsur $\mathrm{H}$ dan $\mathrm{O}$ yang berguna sebagai sumber energi pada unggas (Aswandi, 2016). Selain itu, tepung biji asam jawa juga memiliki kandungan lain yang sangat baik untuk meningkatkan produksi karkas ayam pedaging yaitu kandungan protein, sebagai sumber protein mengandung pigmen yang cukup tinggi seperti xantophyl dan karatenoid sehingga berpotensi sebagai sumber pakan unggas (Sjofjan dkk, 2020). Tepung biji asam jawa (TBAJ) dapat dimanfaatkan untuk dijadikan pengganti bekatul karena kandungan karbohidrat dan protein yang tinggi dibandingkan dengan bekatul. Kandungan lemak yang tinggi pada bekatul menyebabkan bekatul mudah mengalami ketengikan serta kandungan energi yang rendah pada bekatul yaitu sebesar $2860 \mathrm{Kkal} / \mathrm{kg}$ sehingga mudah 
mengenyangkan (Sjofjan et al., 2019).

\section{Pengaruh Perlakuan Terhadap Presentase Karkas Ayam Pedaging}

Hasil analisis statistik menunjukkan bahwa penggunan tepung biji asam jawa sebagai penggati bekatul memberikan pengaruh yang tidak nyata $(\mathrm{P}>0,05)$ terhadap persentase karkas (\%) ayam pedaging. Data pertitungan statistik persentase karkas dari yang tertinggi hingga terendah dapat dilihat pada Tabel 3. Hasil rata-rata persentase karkas (\%) adalah P4 (74,76 $\pm 0,48), \mathrm{P} 3(72,33 \pm 1,79), \mathrm{P} 2(71,30 \pm 0,87), \mathrm{P} 1(70,51 \pm 0,45), \mathrm{P} 0(69,57 \pm 4,56)$. Persentase karkas berbanding lurus dengan berat hidup, semakin meningkat berat hidup maka persentase karkas yang didapatkan semakin meningkat. Menurut Sjofjan and Ardyati (2011), persentase karkas berhubungan erat dengan jenis kelamin, umur serta berat badan. Semakin meningkat umur maka akan mengalami peningkatan pula. Meningkatnya berat hidup ini diikuti dengan menurunnya kandungan lemak abdominal sehingga produksi daging yang dihasilkan akan meningkat. Lemak dan organ dalam merupakan hasil ikutan yang tidak dihitung dalam persentase karkas (Adli dan Sjofjan, 2020).

Umur potong sangat berpengaruh terhadap hasil persentase karkas karena semakin lama umur potong maka semakin besar pula persentase karkasnya (Indra, Tanwiriah dan Widjastuti, 2015). Kenaikan persentase karkas menunjukkan bahwa nilai berat organ dalam rendah dikarenakan penyerapan nutrisi yang baik dari ayam pedaging. Persentase karkas berkaitan dengan berat hidup ayam, jika berat karkas yang dihasilkan tidak mengalami kenaikan akan tetapi persentase karkas yang dihasilkan meningkat dapat dikatakan bahwa berpengaruh terhadap organ dalam (Adli dan Sjofjan, 2020).

\section{Pengaruh Perlakuan Terhadap Presentase Organ dalam Ayam Pedaging}

Organ dalam atau jeroan merupakan organ dari ternak unggas yang telah dipisahkan dari tubuh dan sebelum dibersihkan giblet (hati, empedu, jantung) serta timbunan lemak pada empedal (Widiyawati dkk, 2020). Tekstur pakan, kandungan serat pakan, jumlah pakan yang dikonsumsi serta pakan tambahan berupa grit dapat mempengaruhi besar empedal sehingga berdampak pada beratnya yang juga meningkat. Meningkatnya berat bagian tubuh selain karkas, seperti persentase kepala, kaki, darah, bulu dan organ dalam (Widiyawati dkk, 2020). Pemberian pakan dengan imbangan energi metabolis dan protein yang berbeda memberikan pengaruh yang hampir sama terhadap pertumbuhan organ dalam antara lain hati, jantung. limpa, dan ginjal (Adli dan Sjofjan, 2020). Organ dalam ayam pedaging yang diamati pada penelitian ini antara lain hati, jantung, gizzard dan limpa. 


\section{Pengaruh Penambahan Tepung Biji Asam Jawa Terhadap Persentase Hati Ayam Pedaging}

Berdasarkan hasil analisis penelitian yang telah dilaksanakan yang disajikan melalui Tabel 3, menunjukkan bahwa penambahan tepung biji asam jawa yang digunakan sebagai pakan pengganti bekatul dalam pakan ayam pedaging memiliki pengaruh tidak nyata $(\mathrm{P}>0.05)$ terhadap persentase bobot hati ayam pedaging. Hal ini diduga karena penggunaan biji asam belum bekerja dengan baik dengan campuran pakan lainnya.

Menurut Adli dan Sjofjan (2020) bahwa hati adalah salah satu organ yang sangat vital dalam sistem metabolisme ayam pedaging. Hati pada ayam pedaging terletak diantara gizzard dan empedu. Hati memiliki peranan penting dalam untuk produksi ayam pedaging. Aughey dan Frye (2001) memaparkan secara umum, fungsi hati yaitu sebagai metabolisme glukosa dan lipid, membantu proses pencernaan, absorbsi metabolisme lemak, protein, karbohidrat dan zat besi, detoksifikasi, pembentukan darah merah, dan penyimpanan vitamin yang larut dalam lemak, serta detoksifikasi tubuh terhadap zat toksik hati berperan dalam sekresi empedu. Hati akan mengeluarkan cairan yang berwarna kekuningan dan cairan tersebut tersimpan di dalam sebuah kantung yang disebut kantung empedu yang terletak di lobus sebelah kanan. Aughey dan Frye (2001) menambahkan pakan yang masuk ke dalam duodenum akan memacu kantong empedu untuk mengkerut dan kantong empedu akan mengeluarkan getah empedu ke dalam duodenum yang dapat membantu penyerapan lemak oleh usus halus. Aughey dan Frye (2001) banyak sedikitnya cairan atau getah empedu yang akan keluar tergantung pada beberapa faktor, yaitu faktor aliran darah yang masuk, pakan yang dikonsumsi, kandungan nutrisi yang terdapat dalam pakan yang dikonsumsi, dan sirkulasi empedu. Salah satu faktor produksi getah empedu pada hati ayam tergantung pada pakan yang dikonsumsi, itu sebabnya pakan yang dikonsumsi oleh ayam pedaging haruslah mengandung nutrisi yang cukup dan anti baketeri.

\section{Pengaruh Penggunaan Tepung Biji Asam Jawa Terhadap Persentase Jantung Ayam Pedaging}

Jantung adalah organ yang sangat penting bagi setiap mahluk hidup, terutama bagi ternak ayam pedaging. Jantung memliki peranan yang sangat kritis. Peranan jantung dalam sistem sirkulasi ayam pedaging yaitu sebagai sebagai pemompa darah melalui pembuluh darah menuju seluruh tubuh. Berdasarkan hasil Tabel3 dapat diketahui bahwa Pemberian tepung biji asam jawa sebagai pengganti bekatul dalam pakan memberikan pengaruh yang 
tidak nyata $(\mathrm{P}>0,05)$ terhadap persentase jantung. Selama 35 hari pemeliharaan broiler, pertumbuhan bobot badan ayam bertumbuh secara normal bahkan melebihi dari standar bobot badan ayam pedaging, yaitu lebih dari 1,6 kg/ekor (Aengwanich, and Suttajit, 2010).

Dalam biji asam kandis terdapat kandungan senyawa metabolit sekunder (fitokimia) akan aman dan efektif terhadap bakteri tertentu sehingga baik untuk pertumbuhan dan pelindung bagi kesehatan ternak (Aengwanich, and Suttajit, 2010). Meskipun di dalam Buah Asam Kandis terdapat antioksidan dan antibekteri yang telah dinyatakan oleh Damayanthi dan Listyorini (2006), nyatanya tepung biji asam kandis tidak memiliki efek ataupun pengaruh apapun terhadap pertumbuhan dan pertambahan presentase bobot jantung pada ayam pedaging. Hal ini dikarenakan kandungan nutrisi yang ada pada tepung asam jawa masih sesuai dengan kebutuhan ayam pedaging.

\section{Pengaruh Penggunaan Tepung Biji Asam Jawa Terhadap Persentase Gizzard Ayam Pedaging}

Bedasarkan hasil analisis yang tersaji pada Tabel 3. menunjukkan bahwa penggantian bekatul dengan tepung biji asam jawa dalam pakan broiler memberikan pengaruh yang tidak nyata $(\mathrm{P}>0,05)$ terhadap persentase gizzard ayam pedaging. Gizzard adalah salah satu organ khusus dalam pencernaan, gizzard dimiliki oleh beberapa hewan seperti unggas, reptil, dan beberapa jenis ikan. Gizzard atau rempela termasuk dalam organ pencernaan terbesar pada bangsa unggas. gizzard atau rempela pada unggas mempunyai fungsi yang sama seperti gigi pada mamalia, yaitu untuk memperkecil partikel pakan yang diberikan menjadi ukuran yang lebih kecil. Pakan yang disajikan untuk ayam pedaging berupa pakan komplit yang berbentuk crumble yang kemudian dicampur dengan tepung biji asam kandis sesuai dengan takaran perlakuan masing-masing. Pakan tersebut kemudian dicerna secara mekanis di dalam gizzard atau rempela, selanjutnya diproses ke organ pencernaan usus. Faktor yang mempengaruhi ukuran gizzard yaitu kinerja dari gizzard itu sendiri. Semakin tinggi kinerja gizzard pada ayam pedaging, maka akan semakin meningkat pula ukuran dan bobot ayam pedaging. Hal ini juga sebanding dengan pernyataan yang disampaikan oleh Suryanah dan Anggraeni (2016) bahwasanya ukuran gizzard berubah berdasarkan ukuran makanan yang dimakan, semakin besar ukuran makanan yang dimakan menyebabkan kontraksi yang besar pada gizzard, sehingga menghasilkan ukuran gizzard yang besar. 


\section{Pengaruh Penggunaan Tepung Biji Asam Jawa Terhadap Persentase Limpa Ayam Pedaging}

Berdasarkan hasil dari analisis pelitian yang tersaji pada Tabel 3, dapat diketahui bahwa penggantian tepung biji asam jawa memberikan pengaruh tidak nyata $(\mathrm{P}>0,05)$ terhadap persentase bobot limpa (Aengwanich and Suttajit, 2010). Hal ini disebabkan karena dalam tepung biji asam jawa memiliki zat anti nutrisi yang tidak berpengaruh besar terhadap limpa ayam pedaging. Limpa adalah salah satu organ limfoid yang memiliki fungsi sebagai tempat untuk pematangan dan pembentukan sel antibodi yang kemudian sel antibodi tersebut dapat melindungi dan melawan sel antigen asing atau racun yang datang menyerang tubuh melalui pakan yang dimakan (Aengwanich and Suttajit, 2010). Pada ayam pedaging, limpa berwarna merah sedikit kegelapan, yang letaknya berada di dekat ampela yang memiliki peran sebagai penyimpan sel darah merah (Adli dan Sjofjan, 2020). Limpa ayam pedaging sangatlah unik dikarenakan fibromuskular pada unggas secara histologis terlihat tipis. Berdasarkan pernyataan Aughey dan Frye (2001) bahwa trabekula pada sebagian unggas tidak dapat dapat ditemukan, sehingga limpa pada ayam pedaging terletak di sebelah ampela.

\section{KESIMPULAN}

Pemberian tepung biji asam jawa sebagai pengganti bekatul dalam pakan belum mampu meningkatkan bobot karkas, persentase karkas dan berat organ dalam ayam pedaging.

\section{DAFTAR PUSTAKA}

Adli, D. N., Sjofjan, O., and Mashudi, M. 2017. Dried of poultry waste urea-molasses block (dpw-umb) as potential for feed supplementation. Jurnal Agripet, 17(2), 144-149.

Adli, D. N., and Sjofjan, O. 2018. Nutrient content evaluation of dried poultry waste urea molasses block (DPW-UMB) on In-vitro analysis. Sains Peternakan, 16(2), 50-53.

Adli, D. N., Sjofjan, O., and Mashudi, M. 2018. Nutrient content evaluation of dried poultry waste urea-molasses block (dpw-umb) on proximate analysis. Jurnal Ilmu-Ilmu Peternakan, 28(1), 84-89.

Adli, D. N., Chi, Y., Lee, J. W., and Sjofjan, O. 2019. Supplementation mannan-rich fraction (MRF) and/or combination with probiotic-enhanced water acidifier on dietary female broiler at 28 days as natural growth promoters (NGPs). Research Journal of Advanced Engineering and Science, 4(3), 427-429. 
Adli, D. N., Sjofjan, O., and Mashudi, M. 2019. Nutrient content evaluation of dried of poultry waste urea-molasses block (dpw-umb) on proximate analysis. Jurnal Ilmu dan Teknologi Peternakan, 6(2), 72-76.

Adli, D. N., dan Sjofjan, O. 2020. Meta-Analisis: pengaruh substitusi jagung dengan bahan pakal lokal terhadap kualitas karkas daging broiler. Jurnal Ilmu Peternakan Terapan, $3(2), 44-48$.

Adli, D. N., and Sjofjan, O. 2020. Growth performance, serum blood biochemistry, and intestinal properties of arbor acres broiler fed diets containing mannan-riched fraction (MRF) and probiotic-enhanced liquid acidifier. Buletin Peternakan, 44(2), 34-42.

Aengwanich, W., and Suttajit, M. 2010. Effect of polyphenols extracted from Tamarind (Tamarindus indica L.) seed coat on physiological changes, heterophil/lymphocyte ratio, oxidative stress and body weight of broilers (Gallus domesticus) under chronic heat stress. Animal science journal, 81(2), 264-270.

Aughey E, and Frye, F.L. 2001. Comparative Veterinary Histology with Clinical Correlates. London (EN) : Manson Publising. P: 252-270.

Damayanthi, E., dan Listyorini D.I. 2006. Pemanfaatan tepung bekatul rendah lemak pada pembuatan keripik simulasi. Jurnal Ilmiah Ilmu-Ilmu Peternakan, 13(5), 260-268.

Direktorat Jenderal Peternakan dan Kesehatan Hewan. 2018. Laporan Kinerja Tahun 2017. Direktorat Jendral Peternakan dan Kesehatan Hewan, Jakarta.

Leke, J. R., Sjofjan, O., and Najoan, M. 2013. Egg internal quality and n-3 fatty acids of native chicken fed on skipjack fish (Katsuwonus pelamis. I) industrial waste containing feed. International Journal of Poultry Science, 12(8), 484-489.

Pasaribu, T. 2007. Produk fermentasi limbah pertanian sebagai bahan pakan unggas di Indonesia. Wartazoa, 17(3), 109-116.

Sjofjan, O., and Ardyati, T. 2011. Extracellular amylase activity of amylolytic bacteria isolated from quail's (Coturnix japonica) intestinal tract in corn flour medium. International Journal of Poultry Science, 10(5), 411-415.

Sjofjan, O., Adli, D. N., Hanani, P. K., and Sulistiyaningrum, D. 2019.The utilization of bay leaf (Syzygiumpolyanthum walp) flour in feed on carcass quality, microflora instestine of broiler. International Journal of Engineering Technologies and Management Research, 6(11), 1-9.

Sjofjan, O., Adli, D. N., Natsir, M. H., dan Kusumaningtyaswati A. 2020. Pengaruh kombinasi tepung kunyit (Curcuma domestica val.) dan probiotik terhadap penampilan usus ayam pedaging. Jurnal Nutrisi Ternak Tropis dan Ilmu Pakan, 2 (1),19-24.

Sjofjan, O., Adli, D. N., Djunaidi, I., and Kuncoro, K. (2020). Utilization of biogas liquid waste for starter in the fermentation of rice husk as a potential feed for poultry. Animal Production, 22(1), 24-30.

Suryanah, H. and Anggraeni. 2016. Effects of rations with defferent cation-anion balances on carcass and gibler weight broiler chickens. Jurnal Peternakan Nusantara, 2(1),1-8.

Widiyawati, I., Sjofjan, O., dan Adli, D.N. 2020. Peningkatan kualitas dan persentase karkas ayam pedaging dengan subtitusi bungkil kedelai menggunakan tepung biji asam (Tamarindus indica L) Fermentasi. Jurnal Nutrisi Ternak Tropis, 3(1), 35-40.

Wiranata, G. A., Dewi I. G. A. M. K., dan Indrawati R. R. 2013. Pengaruh energi metabolis dan protein pakan terhadap persentase karkas dan organ dalam ayam kampung (Gallus domesticus) betina umur 30 minggu. Journal of Tropical Animal Science, 1(2), 87-100. 